\title{
Decolonizing Othello in search of black feminist North American identities: Djanet Sears' Harlem duet and Toni Morrison's Desdemona
}

\author{
"Africanism is inextricable from the definition of Americanness"
}

(Toni Morrison, Playing in the Dark)

"For African Canadians, African America signifies resistance, vitality, 'nation', community, grace, art, pride, clout, spirituality and soul. It is a cluster of attractive qualities we crave for ourselves"

(George Elliott Clarke, Odysseys home)

\author{
VICENT CUCARELLA-RAMON* \\ Universitat de València
}

Received: 18/12/2015. Accepted: 5/07/2016.

\begin{abstract}
The plays Harlem duet (1997) by African Canadian playwright Djanet Sears and Desdemona (2012) by Toni Morrison signify upon European texts aiming to carve out a new definition of what it means to be black in North America. Therefore, both texts make for interesting reading in the study of (black) identity construction within US and Canadian contexts for, by revising Shakespeare's Othello, they rethink and rewrite a social and racial reality unrelentingly disrupted by difference and hybridity. Sears' play establishes a specific reading of Canadianness in dialogue with African America to erect a possibility of healing and inclusion, offering a feminist vision of the black self. Similarly, Morrison inscribes the voice of Africa within the US to conclude Sears' account of a feminist and transnational subjectivity for blacks in North America. By reversing the manly ethos that characterized Shakespeare's story and bringing the role of women to the front, both plays succeed in readjusting the Shakespearean story to render a feminist, transnational, cosmopolitan and democratic definition of the black female self.
\end{abstract}

KEYWORDS: black identity, North America, African American, African Canadian, feminist self, Othello.

*Address for correspondence: Vicent Cucarella-Ramón, Universitat de València. C/ General Abriat, 27. La Llosa de Ranes, 46815, Valencia, Spain; e-mail: Vicent.Cucarella@uv.es. 


\section{INTRODUCTION}

The two epigraphs above emphasize the deciding dilemmas African Americans and African Canadians have historically wrestled with, respectively, in their declaration of a national identity. If, as Toni Morrison concedes, "[a]s a metaphor for transacting the whole process of Americanization [...] [the] Africanist presence may be something the United States cannot do without" (1993: 47), the experience of African Canadians has often been intermeshed into a misconception that somehow has managed to blur black Canadian identity into a homogeneous American Otherness. In this light, African Canadian scholar and writer George Elliott Clarke has noticed that " $[\mathrm{u}] \mathrm{ntil}$ the onset of major black immigration from the Caribbean basin in the mid-1950s, European Canadians imagined African Canadians as onceand-always Americans" (2002: 71). Despite Rinaldo Walcott's suggestion that "selfconscious diasporic affiliations offer a way out of the mess that modern nation-states represent for black peoples" (2003: 20), African Canadians' primordial experience is inextricably linked to the slave trade and its aftermath in North America and, therefore, to the history of African America. In this light, it is undeniable that "African American texts enter into and inform African Canadian texts with hegemonic regularity" (Clarke, 2002: 37).

Accordingly, and despite the perpetual white denial of Canada's own history of slavery, the process of literary identity-building for black people both in the US and Canada has definitely been rooted in the consequences of slavery and the African diaspora, that is to say, it has to be inevitably understood by looking back to the European sources of cultural hegemony that shaped the Africanist presence "under pressures of ideological and imperialistic rationales for subjugation" (Morrison, 1993: 8). However, the end of the $20^{\text {th }}$ century, especially after the publication of Paul Gilroy's influential book The black Atlantic: Modernity and double consciousness (1993a), witnessed the reconfiguration and rethinking of the black self "engaged in various struggles towards emancipation, autonomy and citizenship" (Gilroy, 1993a: 16). This, together with the rise of postcolonial studies, spurred black writers to revise hegemonic writings and put them to the service of their quest for identity. ${ }^{1}$

Signifying upon European texts that could attest to a new definition of what it means to be black in North America also helped African Canadians to enhance a sort of black nationalism that, in Clarke's words, emerged "situated at the crossroads of a Pan-Africanism with strong roots in African America" (in Fraile-Marcos, 2014: 115). The representation of a black national character in Canada is upheld at the expense of the intersecting thrusts it shares with the conflicting history that African Americans have for so long fought to preserve. It is at this point when the two plays I am going to analyze cross paths in their search for a genuine identity that can recompose the idea of blackness both in the US and Canada. In this paper I would like to argue that Harlem duet (1997), by African Canadian playwright Djanet Sears, and Desdemona (2012), by Toni Morrison, revise Shakespeare's classic Othello with 
an eye to redefining black (female) identity within US and Canadian contexts. Both plays rely on the Africanist presence to openly insert blackness in the reconfiguration of a new social reality that can balance and apprehend the conjugation of transcultural black epistemologies both in the US and Canada. In spite of black Canadians' penchant of African American cultural representations, Sears' play proposes a specific reading of Canadiannes in dialogue with African America through a feminist vision of the black self that opens up a possibility for healing and inclusion. Similarly, Morrison banks on the voice of Africa within a North American context as her initiative to get over the shortcomings of Gilroy's theoretical framework. In doing so, Morrison concludes Sears' account of a transnational subjectivity for blacks in North America.

Firstly, I will briefly explain how the image of blackness in Europe relied to a great extent on the figure of the Moor to represent the presence of the other. Taking this into account, I will show how Sears' and Morrison's plays engage the figure of the Moor to reflect on the ongoing struggle to assert a black national identity in their respective countries of origin. Through a close reading of both texts, I will highlight how both authors revamp Othello's story to propose an alternative plot that can live up to a modern and feminist reading of Shakespeare's play. In doing so, both plays, I submit, attempt to bear witness to and unravel the two aforementioned epigraphs that open this article.

\section{LITERARY CONTEXT: READING THE MOOR AS AN AFRICAN DIASPORIC IDENTITY}

Although British explorers did not touch African shores until the mid-16 ${ }^{\text {th }}$ century, blackness was already seen in a negative light in the Western mindset. This was so because church fathers, such as St. Jerome or St. Augustine, had equated the idea of blackness with something villainous through a deceptive reading of the Bible. This accepted misreading pictured Africans as Ham's sons and, therefore, they were condemned to be "servants of servants" due to his father's disrespectful act of looking upon the Father's nakedness as he lay down in the tent. From then on, blackness became tantamount of dirtiness and savagery. Years later, with the revival of travel books, such as Leo Africanus' Geographical history of Africa, the image of Africans as monsters and non-rational beings was dispelled throughout Europe. As Ana $\mathrm{M}^{\mathrm{a}}$ Manzanas explains, "[i]nstead of bridging the cultural distances between Europe and Africa, travel literature seemed to emphasize the difference between western thought $[\ldots]$ and African culture. The sense of 'difference' inherent in travel books confirmed Europe's hegemony and superiority" (1996: 193). New expeditions to Africa from various nations reinforced the mythical associations of blackness as despicable, conveying in such a way the Africans' monstrous traits globally. 
In subsequent years, the North American slave system contradicted the egalitarian democratic ideals that the nascent nation of the United States of America had articulated in the Declaration of Independence. The exclusion of people of African descent from the US polity soon resulted in the institutionalization of oppression and marginalization, to the extent that blackness became an "Ellisonian 'ectoplasmatic' presence" (Clarke, 2002: 326).

This negative picture that blackness conveyed almost throughout five centuries was reversed in the first half of the $20^{\text {th }}$ century by black writers who aimed to reclaim a new reading of the black self. After Alain Locke published The new negro (1999) in the heyday of the Harlem Renaissance, some African American writers reclaimed the presence of the Moor, the African in Europe, as a figure through which to reconsider the value of transnational black identities. The Moor became central to the ideas of difference at the heart of Europe and pivotal to understand the meaning and role of race and racism in the medieval and Renaissance periods. In due course, the Moor was aptly rescued as a topos for black writers who yearned to redefine black identity.

The appraisal of these 'imaginative geographies', as Edward Said would call them (1979), allowed black writers to "challenge socially-spatially constructed identities and reconfigure global relations" (Ramos, 2015: 23) and also to enlarge the process of North American identity-building or, in María Christina Ramos' words, to "encourage visions of global black identities- identities in motion and unbounded from traditional constructionsthat can forge new forms of relations and alliances with others" (2015: 23).

In this way, African American writers such as Richard Wright in Pagan Spain (2002), Frank Yerbi in Novel of Moorish Spain (1965) or Lori Tharps in Kinky Gazpacho (2008) employed the figure of the Moor as a metaphor for understanding various forms of racial identity in the Unites States. Similarly, and proving that African Canadians "utilize African American texts as historical-cultural icons to define African Canadian experience" (Clarke, 2002: 72), black Canadian writer Kim Barry Brunhuber's debut novel, Kameleon man (2003), follows suit and also uses the figure of the Moor to delve into the definition of the protagonist, Stacey Schmidt, a mixed-race Canadian young man who works as a fashion model. So, when he is denied his Canadianness due to his skin color and travels to Europe in search of a better future, he considers to settle in Spain attracted by the historical association that bonded Spaniards with Arabs_-and, therefore, to blackness-in medieval times. Upon his arrival to Andalusia he unabashedly expresses: "[i]f I could pick a time and place to live in, I would choose here [Andalusia] in the days of Tarik, when a black guy became the master of Spain and Africa began at the Pyrenees" (Brunhuber, 2003: 273).

In the same vein, both Desdemona and Harlem Duet draw from Shakespeare's Othello to think about identity and racialized subjects. However, contrary to the examples hitherto given, both writers focus on women and hence take a different tack in the retelling of the story. The story of the Moor of Venice serves to reflect upon blackness in the contemporary US and Canadian contexts. The fact that both plays portray a female protagonist extends as

(C) Servicio de Publicaciones. Universidad de Murcia. All rights reserved. IJES, vol. 17 (1), 2017, pp. 83-97 Print ISSN: 1578-7044; Online ISSN: 1989-6131 
well as revises black subjectivity from a feminist point of view, something that is twice as relevant, taking into consideration the manly tone that Shakespeare's Othello oozes and the masculinity that has been traditionally involved in the identity-building process of black subjectivity.

\section{HARLEM DUET: BLACK CANADA MIRRORING BLACK AMERICA}

Djanet Sears' Harlem duet is not just a reverse reading of Othello, but it also stands as a cultural fusion of literary voices that aim to accommodate different pictures of blackness in North America. So, taking as a key element the story of the Moor of Venice, Sears creates a play that revises the tensions resulting from discussions of racial identity documenting its cultural, historical and national imbrication with gender identity. In an interview for Canadian Adaptations of Shakespeare Project, Sears admitted that the starting point for her acclaimed play Harlem duet resulted from the long-term questions: "how could I begin to look at Othello from my own perspective? What do I think of him?" (Buntin, 2004). Indeed, Harlem duet is Sears' appropriation of the myth of the Shakespearean Moor to bring awareness of the necessity of reclaiming the subjectivity of African Canadians within the nation-state. Sears modernizes the story by imagining Othello's life with his first black Canadian wife in order to encourage Canadians to focus on the intersecting zone where race, gender and identity-building meet. In the play Othello leaves Billie, his African Canadian wife of nine years, for Mona, a white woman and fellow faculty member. The separation is somewhat traumatic and unearths some issues that revolve around the representation of black identity in North America. ${ }^{2}$ Billie, who is emotionally devastated, throws herself into a deep analysis of her marital relation, questioning black identity versus black perception of identity. The conflicting relationship of Billie and Othello is also played out in two other parallel plotlines featuring the same characters, only named HE and SHE in 1920 and HIM and HER, whose timeline dates back to 1860, the eve of the outbreak of the American Civil War.

The three stories counterbalance each other imitating a syncopated rhythm that sheathes the whole story. In truth, music is of great importance in the play since every act is introduced by a piece of blues or jazz music in an overt literary and theatrical strategy that vouches to racialize the story. In a way, characters express themselves also through black music. As an African Canadian who has placed a black Canadian woman in an American context, Sears brushes up Toni Morrison's assumption that "[m]usic provides a key to the whole medley of African American artistic practices" (Gilroy, 1993b: 181) by embracing black music within the black Canadian experience. This transnational account of black subjectivity links the US and Canada and opts for a cosmopoliticized inclusion rather than for a national exclusion. Overshadowing the effects of the burdensome history of slavery and 
refreshing the cultural links of the African diaspora, Sears' bold assay to think blackness beyond Canada is the creation of an African Canadian woman that is related to a historical European figure located in African America.

Canada holds a paradoxical position as both a sanctuary for ex-slaves and as a country that has historically mistreated its black population. This national double consciousness defines Billie's attachment to the US and is at the core of her idealistic image of her host country.

Although Billie's sister-in-law, Amah, refers to Nova Scotia-and therefore to Canada - as a "haven for slaves way before the underground railroad" (Sears, 1997: 45), it is no coincidence that Billie has escaped from Nova Scotia fleeing a tight context of anti-black racism. Out of this fact Sears seems to evoke the tragic events of Africville and thus pays tribute to African Canadian history and culture. Africville was a bountiful community of exslaves that settled in Halifax, Nova Scotia, until the first half of the $20^{\text {th }}$ century creating a neglected yet vindicative community of African Canadians. In the 1960s, Halifax razed this black town to the ground and made its inhabitants flee the area in order to develop the Murray Mackay Bridge. The violence that came along with the removal has erected Africville as a national symbol of the struggle for the recognition of an African Canadian identity. The repressed history of black Canada intertwined in a European plot-Othello-brings to mind the overlapping history that links Europe to the colonization of Canada in an appraisal of a new version of Canadianness. That is why when Billie's father, named Canada in a symbolical move that helps her reconcile with her racialized subjectivity, comes back to visit her, he recognizes, speaking about Nova Scotia: "I'm thinking of heading back there myself" (Sears, 1997: 82). With such a statement, Billie dissolves the national boundaries separating Canada and the US and voices and links the racial violence inscribed in the silenced cultural history of Africadians-George Elliott Clarke's neologism to refer to African Canadians from the Maritime provinces-with the boasted history of African America. Billie's identification with her black southern neighbors makes her cast a black subjectivity "through new time-spaces that disturb the geographies and temporalities, the borders and sedimented histories left behind by the hemispheric expansion of empires in the Americas" (Siemerling, 2015: 28). The recognition of this transcultural black self not only changes the influential map that Paul Gilroy evoked in The black Atlantic, but it further underlines "that black Atlantic spirits of modernity challenge any singular perspective and account" (Siemerling, 2015: 30).

It is on behalf of this fresh conception that her political awareness for putting up a fight with Othello's assimilating views towards race draws the line of their failed liaison. Shakespeare broke the relationship out of jealousy, while Sears aptly tears love aside due to racial matters.

Othello represents what Spivak coined as 'sanctioned ignorance' (2003) when he asserts: "what does Africa have to do with me? [...] I am American [...] I am not my skin. 
My skin is not me" (Sears, 1997: 73-74). He appears to be complicit with the forged evolution of racialization in the West at the end of the $20^{\text {th }}$ century, namely, from the celebration of difference to the enhancement of racial sameness, representing all races wrapped up into one "[in] an attempt to erase the political significance of race" (1996: 163), as Celia Lury rightly perceives. Conversely, Billie stems from the traditional African American discourses of empowerment in her response to Othello's racial capitulation. Her readings of African mythology and the Great Chain of Being connect the awareness of her black self-representation to Africa across the black Atlantic, pointing directly to Gilroy's theoretical shortcomings. ${ }^{3}$ Billie's empowerment exceeds then the Canadian realm to link the experience of African Canadians to the US, the Caribbean and Africa. Her account of blackness differs completely from Othello's own perspective. The discussions of racial categories as central for the understanding of the black self in North America are thus polarized.

In Harlem duet, Othello is far from the strong man that Shakespeare created, responding rather to what Michel Pêcheux calls the 'good subject' (1982), who freely identifies with the dominant ideology and willingly assimilates into it. If Othello peddles his blackness in exchange for acceptance, Billie embodies the counteridentification of such strategy. Reappropriating Sojourner Truth's “Ain't I a woman?”, she makes it clear that her definition as a black Canadian in black America can only be expressed, and understood, in terms of race and ethnicity: "We are black. Whatever we do is black" (Sears, 1997: 75, 54). Linking the black experience of the US and Canada, Sears presents a woman that foreshadows the ideas of a man and who hails her black identity openly in search of selfdefinition.

Although Othello hovers in the background of the play, Sears creates an empowered woman who, contrary to Desdemona, does not only contest Othello's views but also instructs him in the debate of racial categorization: "No, no in America this race shit is classic behavioral disorder. Obsession. Phobias. Delusions [...] Any one or combination of these can produce behaviors which categorize oneself as superior and another as inferior" (Sears, 1997: 52). In Shakespeare's play Othello is othered for being the only black man, and he is marked in Harlem duet because of his desire to assimilate. The result is the rising of Billie as the coherent and strong character. In other words, Billie's voice is plumbed as the only feminine authoritative voice; in fact, (Desde)Mona is out of picture for the whole play and does not utter a single word.

Through the use of historical facts, the continuous references to black remarkable figures-Booker T. Washington, Martin Luther King or Malcom X among many others-and Billie's civil rights fighter voice, Sears showcases that social and racial dysfunction can be overcome by paying tribute to a feminist reading of black history that can unite both the US and Canada. Indeed, Sears' tribute to black women makes Billie embrace and vindicate a past that bespeaks slavery and suffering. In this way, Billie adopts her grandmother's name, Sybil 
(Sears, 1997: 101), a former slave, displaying a national pride that follows not only her roots but also her own race.

Pride and freedom will go hand in hand in the play and so, when at the end of the play Billie realizes that Othello is getting married to a white woman, (Desde)Mona, Billie's determinacy leads her to poison the handkerchief he gave her when she brings it back to him. The handkerchief, which represented submission in Shakespeare's play, transfigures here into a weapon in the hands of a self-sufficient woman. Eventually, she is discovered and brought to a psychiatric hospital. With this sour ending Sears concludes by denouncing the way black women, both in the US and Canada, have for so long been taken for granted when it comes to fighting for self-definition and self-assertion. Although Billie remains strong throughout the play, she ends up locked in a mental asylum that thwarts every idea of self-definition that she has tried to convey along the story. However, there seems to be a silver lining since the final shot reveals Billie coming to clarity when her father arrives to pay her a visit. Like the blooming rose in Aretha Franklin's "Spanish Harlem" (the song that Billie and her father hum along in unison), the act of reconciliation opens the way for a future of understanding when both hold their hands; that is, when black Canada and black America get in touch.

\section{TONI MORRISON'S DESDEMONA: THE AFRICAN PAST TAKES AMERICAN STAGE}

In line with previous accounts to reimagine the representation of Shakespeare's Desdemona such as Desdemona: A play about a handkerchief (1993) by Paula Vogel, and Goodnight Desdemona (Good morning Juliet) (1988) by Ann-Marie MacDonald, Toni Morrison's Desdemona (2012) appropriates the myth of the Shakespearean Moor in a US context. However, Morrison takes a different tack from her predecessors' attempts to delve into the subjectivity of Desdemona by offering a diasporic consciousness that gives voice to Africa, and offers the Shakespearean characters the possibility of bridging gender differences. In Morrison's work the role of the main characters-Othello and Desdemona-is reversed and it presents an ethnic and feminist vision of the tragedy that aims to fill in the gaps that the story left open in the $16^{\text {th }}$ century by redefining the identity of women and reconfiguring the black consciousness of the original play. In Desdemona, Morrison imagines the title character unfurling her thoughts and secrets to the African maid who raised her on African songs and stories, and focuses on themes of gender issues, racism and oppression. Taking an open feminist posture, Desdemona also makes amends with her husband Othello aiming to come full circle and to finally display the egalitarian ending that the Shakespearean tragedy lacked.

Morrison's intentions are clear-cut from the outset of the story when Desdemona springs off the page and confesses: "I am not the meaning of a name I did not choose" 
(Morrison, 2012: 13). The feminist stance is evident from the very beginning of this new reading of the story, for Morrison is doing away with the onomastic determinism that foregrounded the destiny of people depending on their names. In Morrison's Desdemona women decide, act and choose. Desdemona is here far away from the coy Shakespearean construction and takes the lead of her self-definition. This postcolonial rendition allows Morrison to zero the story in the afterlife, after all the characters have passed away. I consider this afterlife from which the characters speak as an ethnoscape, following the postcolonial anthropologist Arjun Appadurai. According to him, the ethnoscape refers to the "landscape of persons who constitute the shifting world", or 'imagined worlds', that ultimately are able to "contest and sometimes even subvert the 'imagined worlds' of the official mind" (1990: 297). Indeed, Morrison prompts the audience to relinquish Shakespeare's setting and creates a new one in which women can get empowered and gain centrer stage. The afterlife is the ethnoscape where Morrison's characters are ready to forgive each other, make amends and speak the lines that the Shakespearean characters could not utter.

The politics of forgiveness infuse the play and reinforce the way in which Morrison sews back the pieces of the crippled plot that Shakespeare left outside the story and off stage. In Desdemona, Madame Brabantio and Soun (that is, the mothers of Desdemona and Othello), get a voice and engage in a healing debate with the purpose of bridging difference with regards to class and race. Through a related female kinship that unites both women's suffering for their offspring, Morrison balances the transcultural hegemonic discourses that try to evince difference as a derogatory asset and opts for exoneration as a means for the construction and full understanding of a multiethnic social reality. Soun's claim that "we have much to share" is summarized in a covenant of forgiveness that pulls together two women of different class and race, white and black, in a touching move that reveals a transnational and transcultural feminist union: "We build an altar to the spirits who are waiting to console us" (Morrison, 2012: 27). Sharing each other's pain is the way in which both women gain subjectivity and have their say pretending to foster the eventual redemption of all the characters and envisioning women as the synergistic force to overcome difference.

The product of this new conception of womanhood is Desdemona, who, being center stage, admits to "live in the roots and heads of the trees", taking the biblical Eve as a reference "in whom all strength is rooted, grows and gives meaning" (Morrison, 2012: 14, 15). Morrison is thus providing Desdemona with a subjectivity of her own using a common trope in African American women writing and, therefore, roots the revision of the Shakespearean classic in the US literary tradition. Black women writers have used trees, as an image of life, to publicly gather self-esteem and acknowledge themselves a sense of being. Toni Morrison herself used the image of the tree to convey the resurgence of black female subjectivity in her masterpiece Beloved (1987) and in Song of Solomon, where Milkman and Guitar refer to Pilate as "this lady who had no navel and looked like a tall tree" (2004: 39). Similarly, this trope can be found in Alice Walker's acclaimed novel The color purple 
(1983), when Celie admits: "I make myself wood. I say to myself, Celie, you're a tree" (1982: 22); or in Zora Neale Hurston's literary milestone Their eyes were watching God, where Nanny puffs up to Janie: "You know, honey, us colored folks is branches without roots" (1990: 31). Running such course, the image of the tree as a symbol of growth, thrift and fulfillment of black womanhood, and voice links Desdemona to Barbary, her African nurse and the other major feminine figure that finally gets to speak in Morrison's rendition of Shakespeare's classic. If, in the primeval text, Barbary meant Africa and equated barbarism, savagery and silence, Morrison not only gives her a voice but also the opportunity to tell her story-herstory_, inserting herself into history and voicing Africa for the first time in a Shakespearean story. When Desdemona and Barbary reunite onstage the African maid refuses to be called Barbary and bespeaks her autonomy by voicing her mind: "I mean you don't even know my name. Barbary? Barbary is what you call Africa. Barbary is the geography of the foreigner, the savage. Barbary? Barbary equals the sly, vicious enemy who must be put down at any price; held down at any cost for the conquerors' pleasure. Barbary is the name of those without whom you could neither live nor prosper" (Morrison, 2012: 45).

The black woman crows the white woman and renames herself Sa'ran, meaning 'joy', reversing the story in a wily move that situates the colonized one step ahead of the colonizer. This ethnoscape that "affects the politics of and between nations" (Appadurai, 1990: 297) is where Morrison breaks the chains of colonization and brings to the fore the African diasporic self that constitutes an important element in the formation of what we know today as United States. Sa'ran's acquisition of autonomy is performed when she sings a new version of the willow tree ${ }^{4}$ that in Shakespeare led to the foreboding of tragedy, while in Morrison epitomizes the resurrection of black subjectivity. Moreover, and proving once more Morrison's penchants on the Bible, ${ }^{5}$ she sings the song three times, with the resulting biblical imagery that such number encapsulates. ${ }^{6}$

Morrison parodies, in a hutcheonian way that marks the intersection of invention and critique of texts that counteract each other, the re-definition of the African self by correcting, and therefore contemporizing, the ethnic cross-cultural female dialogue violently ablated in her masterpiece Paradise (1998). This novel, which closes up Morrison's acclaimed trilogy, has been extensibly analyzed taking into account the interactive difference that the multiethnic women that compose the Convent represent in the process of identity-formation within the US. The nature of the Convent, as a site where a fluid hybridization of opposite identities takes place, is revisited for inclusion in Desdemona. So, if Paradise opens with a cite that ends up saying "They will not die again" (Morrison, 1998: preface), in reference to the women that act as a catalyst outlet to expose the Manichean way in which (African) Americans have established their identity, in Desdemona, after Sa'ran states "I will never die again" in her final musings of her song, Desdemona quickly adds: "We will never die again" (Morrison, 2012: 49) - a move that points to the restoration of the female roots, so often underestimated in the study of the transatlantic black self, in order to "signal modernity" 
(Morrison, 1993: 52) and accuracy when it comes to the representation of the contemporary black female subjectivity. Or, in Lenore Kitts' words, “Desdemona's dialogue with Barbary [...] functions to expose and transform the wounded identities at the heart of Shakespeare's play" (2014: 259).

Morrison puts to use the 'imagined world' that Appadurai conjures up to overtly contest oppressive ideologies that have for so long colonized and corrupted societies. As such, it is evoked by Desdemona in an admonition that signals the pitfalls of the globalized world when considering the conciliation of transethnic epistemologies: "The world is alive and even if we kill it, it returns fresh, full-throated and hungry for time and space in which to thrive. And if we haven't secured the passionate peace we yearn for, it is because we haven't imagined it. Is it still available, this human peace? In our privileged position in timelessness, our answer is a roar" (Morrison, 2012: 56).

The timelessness that defines the ethnoscape in which the characters act is the perfect device to launch a social critique towards the social chaos that implies not embracing difference as a positive trait. Desdemona's poignant exordium posits the necessity of reorienting new imaginations of the state so as to hold multiple ways of social representation. In line with this polyvocal exercise, Morrison rereads Shakespeare's Othello through Jacques Derrida's rehabilitated vision of cosmopolitanism in which "forms of solidarity [are] yet to be reinvented" (Derrida, 2005: 4).

Henceforth, at the end of the play Sa'ran has reestablished her denied identity and Desdemona and Othello make amends in a wondrous scene in which an empowered woman compels him by admitting: "I was the empire you had already conquered. Alone together we could have been invincible" (Morrison, 2012: 54). In an extremely symbolic stance, Morrison ends the play with Sa'ran's voice, providing a restoration of roles, for in Shakespeare the concluding lines of a play were spoken by a character whose rank could match the hierarchy of the audience. Contrarily, now, as Anthony Pennino notes, Morrison has reinstalled "Shakespeare's place in a contemporary conception of global literature" (nd: 5).

In the conclusion of her debut novel The bluest eye, Toni Morrison tells readers that regarding black female subjectivity "the loved one is shorn, neutralized, frozen in the glare of the lover's inward eye" (2007: 313). Forty-two years later, when the African diasporic self has had her say in the US through the lens of a timeless classic, Morrison gets Desdemona to top the story off with a transcultural and yet beautiful mode of social atonement: "[W]e will be judged by how well we love" (Morrison, 2012: 56). 


\section{CONCLUSION}

Although Sears' and Morrison's plays could be charged with a certain belatedness apropos of the competing discourses that allowed for a new construction of blackness, it is also a fact that both works have produced a new alternative black and feminine voice that emerges as a counter-narrative to the long-dominant white-supremacist patriarchal metanarrative of the Western canon. They also relegate the importance of black subjectivity beyond the realms of their respective nations striving to propose a transcultural and transnational account of the new black epistemology.

Hence, Harlem duet and Desdemona seem to corroborate Homi Bhabha's idea of the nation as a "heterogeneous, changeable grouping, ambivalent in its constitution, split by otherness within, and hybridized at its every contact with the Other" (Childs \& Williams, 1997: 140). Sears' and Morrison's plays bring forth another version of Shakespeare's plot to opt for a transnational, hybrid and fluid sense of black identity that can all the more explain the heterogeneous subjectivities that have historically altered the racial makeup of North America. In this way, the United States and Canada stand as the "Third Space" whereby new black epistemologies conflate eluding the politics of polarity to "emerge as the others of our selves" (Bhabha, 2001: 39). Acknowledging that North Americans have always chosen to "talk about themselves through and within a sometimes allegorical, sometimes metaphorical, but always choked representation of an Africanist presence" (Morrison, 1993: 17), Sears and Morrison reinscribe the black experience — especially black female experience-in a national imaginary that, though intent on erasing it, has nevertheless been partially shaped by its relationship to the Africanist presence in the US and the eventual sociocultural impact it has made on Canada. In doing so, both plays confirm and exemplify the epigraphs that make the heading of the article since they corroborate how the transnational Africanist expression is present in the representation of blackness not only in the US but also in Canada and in the intersection that results from the intertwining of both cultures.

Despite the publication of Gilroy's Against race: Imagining political culture beyond the color line (2000), which inaugurated the global construct of a post-racial era and, therefore, summoned scholars to get over theories of race disregarding the essentialist tone that related race to social construction, Sears' and Morrison's plays demonstrate how the concept of racial identity-building, when it comes to representing the identity of African Americans and African Canadians, is a strategic feature that can only be addressed properly in a globalized conception of ethnicity that builds upon the roots and routes of the Black Atlantic.

Contrary to Gilroy's call to do away with "the old, modern idea of "race"" in the literary representation of "multicultural, social and political life" (2000: 6) and risking, at the same time, the chance that The black Atlantic could serve to reinforce black male subjectivity, Djanet Sears and Toni Morrison flesh out Paul Gilroy's studies and readjust the 
Shakespearean story to render a feminist, transnational and cosmopolitan definition of the black self.

\section{NOTES}

1 Many renditions of European canonical texts emerged alongside the postcolonial momentum. Among the noteworthy examples that have evolved into classics of postcolonial literature we find the novel A grain of wheat (1967), by Kenyan author Ngugi wa Thiong'o, which recasts Shakespeare's The Tempest. A year later appeared the now highly acclaimed Une tempête, by Martinican poet and playwright Aimé Césaire. The massive critical attention afforded by postcolonial scholars to Césaire's adaptation of The Tempest "pour un theatre negre", as its subtitle puts it, has tended to obscure the fact that just one year earlier Ugandan playwright Murray Carlin staged Not now, sweet Desdemona (1996), an utterly beautiful and raw exploration of the inherited historical and cultural burdens of both racial prejudice and white liberalism within the context of South African Apartheid. Across the Black Atlantic there were some AfroCaribbean writers who also rewrote canonical texts infusing them a diasporic flavor, such as Jean Rhys's classical Wide Sargasso See (1999), which revises Jane Eyre from the perspective of Bertha Antoinette Mason; Barbadian poet and historian Edward Kamau Brathwaite's poem "Caliban" (1973); or Maryse Condé's Windward heights (2008), a powerful black Caribbean rewriting of Wuthering heights.

2 Djanet Sears' first play, Afrika solo (1990), opened the way for the representation of blackness within the Canadian context since it became the first play to be published by an African Canadian woman playwright. In it, Sears already delved into concepts such as identity, race, femininity and social representation. These themes will also be dealt with in Harlem duet.

3 As I have argued elsewhere (Cucarella-Ramon, 2015), the publication of Paul Gilroy's The black Atlantic: Modernity and double consciousness in 1993 marked an ontological shift in the recognition of a diverse and conflicting black experience and their cultural production. There exists an established consensus on the impact and groundbreaking potential of Gilroy's work as it propounded a global reconfiguration of the notion of a black multilayered self. Gilroy positioned black consciousness from the margins to the center engaging a transnational and transcultural debate that contributed to secure the black subject as "a central symbol in the psychological, cultural, and political systems of the West as a whole" (1993a: 158). However, in the late 1990s Gilroy's theory generated discussions over its shortcomings namely because new readings of The black Atlantic brought forth the absence of the social realities of Africa, the Caribbean and Canada within its theoretical framework. Linking the influence and inspiration of African Canada and African America is Sears' move to build upon Gilroy's contention in his The black Atlantic.

4 The character of Sa'ran was performed by African composer and musician Rokia Traoré, an element that also helped to vividly bring the Africanist presence into real life.

5 For a detailed and complete account of Morrison's penchants on the Bible throughout her literary career see Toni Morrison and the Bible: Contested intertextualities, edited by Shirley A. Stave (2006).

6 According to the Bible, Jesus prayed three times in the Garden of Gethsemane, he was placed at the cross at the third hour of the day, three hours passed while Jesus died, and he was dead for three entire days and three full nights. Afterwards, he resurrected. Aptly, Sa'ran's relation to number three resonates with resurrection, which could be directly applied to her revived subjectivity in comparison to the silent and indirect role that she was given by Shakespeare. 


\section{REFERENCES}

Appadurai, A. (1990). Disjuncture and difference in the global cultural economy. Theory, culture and society, 7(2), 295-316.

Bhabha, H. (2001). The location of culture. (4th ed.). London: Routledge.

Brathwaite, E. K. (1973). Caliban. In The Arrivants (pp. 192-196). Oxford: Oxford University Press.

Brunhuber, K. B. (2003). Kameleon man. Vancouver: Beach Holme.

Buntin, M. (2004, March). An interview with Djanet Sears. Canadian Adaptations of Shakespeare Project. Retrieved August 15, 2015 from http://www.canadianshakespeares.ca/i dsears.cfm.

Carlin, M. (1996). Not now, sweet Desdemona: A dialogue for black and white within the realm of Shakespeare's Othello. Nairobi: Oxford University Press.

Césaire, A. (2000). A Tempest. (Philip Crispin, Trans.). London: Oberon (Original work published 1969).

Childs, P. \& Williams, P. (1997). An introduction to post-colonial theory. London: PrenticeHall/ Harvester Wheatsheaf.

Clarke, G. E. (2002). Odysseys home: Mapping African Canadian literature. Toronto: University of Toronto Press.

Condé, M. (2008). Windward heights. New York, NY: Soho Press.

Cucarella-Ramon, V. (2015). Liminality and (trans)nationalism in the rethinking of African Canadian subjectivity: Esi Edugyan's The second life of Samuel Tyne. Canada and Beyond: A journal of Canadian literary and cultural studies, 5, 27-50.

Derrida, J. (2005). On cosmopolitanism and forgiveness. (Mark Dooley \& Michael Hughes, Trans.). London / New York, NY: Routledge (Original work published 2001).

Fraile-Marcos, A. M. (2014). The transcultural intertextuality of George Elliott Clarke's African Canadianite: (African) American Models Shaping George \& Rue. African American Review, 47(1), 113-128.

Gilroy, P. (1993a). The black Atlantic: Modernity and double consciousness. London / New York, NY: Verso.

Gilroy, P. (1993b). Living memory: A meeting with Toni Morrison. In P. Gilroy (Ed.), Small acts: Thoughts on the politics of black cultures. (pp. 175-182). London: Serpent's Tail.

Gilroy, P. (2000). Against race: Imagining political culture behind the color line. Cambridge, MA: Harvard University Press.

Hurston, Z. N. (1990). Their eyes were watching God. New York, NY: Perennial Library.

Kitts, L. (2014). The sound of change: A musical transit through the wounded modernity of Desdemona. In A. Lanier Seward \& J. Tally (Eds.), Toni Morrison: Memory and meaning (pp. 255-269). Jackson, MS: University Press of Mississippi.

Locke, A. (1999). The New Negro: Voices of the Harlem Renaissance. New York, NY: Touchstone.

Lury, C. (1996). Consumer culture. New Brunswick, NJ: Rutgers University Press.

Manzanas, A. M. (1996). The making and unmaking of a colonial subject: Othello. Miscelánea: A journal of English and American studies, 17, 189-205.

McDonald, A. (1998). Goodnight Desdemona (Good morning Juliet). Toronto: Grove Press.

Morrison, T. (1987). Beloved. New York, NY: Plume.

Morrison, T. (1993). Playing in the dark: Whiteness and the literary imagination. London: Picador.

Morrison, T. (1998). Paradise. New York, NY: Alfred A. Knopf.

Morrison, T. (2004). Song of Solomon. (3rd ed.). New York, NY: Vintage.

Morrison, T. (2007). The bluest eye. New York, NY: Vintage.

Morrison, T. (2012). Desdemona. London: Oberon Books.

Pêcheux, M. (1982). Language, semantics, and ideology. (Harbans Nagpal, Trans.). London: Palgrave Macmillan (Original work published 1972).

Pennino, A. (nd). "A Maid Call'd Barbary": Toni Morrison, Desdemona and the voice of Africa. Retrieved from 1 September, 2015 from https://www.academia.edu/14669388/_A_MAID_ CALL D BARBARY TONI MORRISON DESDEMONA AND THE VOICE OF AFRI CA.

Ramos, M. C. (2015). Mapping the World Differently African American. Travel Writing About Spain. València: Biblioteca Javier Coy d'Estudis Nord-americans. 
Rhys, J. (1999). Wide Sargasso Sea. (Judith L. Raiskin, Ed.). New York, NY: Norton.

Said, E. (1979). Orientalism. New York, NY: Knopf Doubleday.

Sears, D. (1990). Afrika solo. Toronto: Sister Vision.

Sears, D. (1997). Harlem duet. Toronto: Scirocco Drama.

Siemerling, W. (2015). The black Atlantic reconsidered: Black Canadian writing, cultural history, and the presence of the past. Montreal / Kingston: McGill-Queen's University Press.

Spivak, G. C. (2003). Death of a discipline. New York, NY: Columbia University Press.

Stave, S. A. (Ed.) (2006). Toni Morrison and the Bible: Contested intertextualities. New York, NY / Oxford: Peter Lang.

Tharps, L. L. (2008). Kinky Gazpacho: Life, Love and Spain. New York, NY: Washington Square Press.

Thiong'o, N. (1967). A grain of wheat. London: Heineman.

Vogel, P. (1993). Desdemona: A play about a handkerchief. New York, NY: Dramatists Play Service, Inc.

Walcott, R. (2003). Black Like Who? Writing Black Canada. (3rd ed.). Toronto: Insomniac Press.

Walker, A. (1982). The color purple. New York, NY: Washington Square Press.

Wright, R. (2002). Pagan Spain. Jackson, MS: University of Mississippi Press.

Yerbi, F. (1965). An Odor of Sanctity: A Novel of Moorish Spain. New York, NY: Dial Press. 